\title{
Electroneutral efflux of $\mathrm{Ca}^{2+}$ from liver mitochondria
}

\author{
Martin D. BRAND \\ Department of Biochemistry, University of Cambridge, Tennis Court Road, Cambridge CB2 1QW, U.K.
}

\author{
(Received 16 August 1984/Accepted 26 September 1984)
}

1. Respiring liver mitochondria were allowed to export $\mathrm{Ca}^{2+}$ on the endogenous $\mathrm{Ca}^{2+} / n \mathrm{H}^{+}$antiporter in the presence of Ruthenium Red (to inhibit uptake on the $\mathrm{Ca}^{2+}$ uniporter) until a steady state was reached. 2. Addition of sufficient of the ionophore A23187 (which catalyses $\mathrm{Ca}^{2+} / 2 \mathrm{H}^{+}$exchange) to bring the $\mathrm{Ca}^{2+}$ and $\mathrm{H}^{+}$ gradients into equilibrium did not alter the steady state. 3 . Thermodynamic analysis showed that if a $\mathrm{Ca}^{2+} / n \mathrm{H}^{+}$exchange with any value of $n$ other than 2 was at equilibrium, addition of $\mathrm{A} 23187$ would have caused an easily measurable change in extramitochondrial free $\left[\mathrm{Ca}^{2+}\right]$. 4. Therefore the endogenous carrier of liver mitochondria catalyses electroneutral $\mathrm{Ca}^{2+} / 2 \mathrm{H}^{+}$antiport.

Mitochondria take up $\mathrm{Ca}^{2+}$ electrophoretically, by $\mathrm{Ca}^{2+}$ uniport. They release it on an antiporter by exchange with $\mathrm{H}^{+}$(in many tissues, including liver) or $\mathrm{Na}^{+}$(in tissues such as heart and brain) (Saris \& Akerman, 1980; Nicholls \& Crompton, 1980; Nicholls \& Åkerman, 1982). This calcium cycle is thought to be important in regulation of intra- and extramitochondrial $\left[\mathrm{Ca}^{2+}\right]$ (Denton \& McCormack, 1980; Williamson et al., 1981).

The reaction carried out by the antiporter in liver mitochondria is thought to involve $\mathrm{H}^{+}$because artificially imposed $\mathrm{pH}$ gradients are able to cause $\mathrm{Ca}^{2+}$ uptake or release ( $\AA$ kerman, 1978; Fiskum \& Cockrell, 1978). However, it has not yet been clearly established whether the carrier catalyses $\mathrm{Ca}^{2+} / 1 \mathrm{H}^{+}, \mathrm{Ca}^{2+} / 2 \mathrm{H}^{+}$or $\mathrm{Ca}^{2+} / 3 \mathrm{H}^{+}$antiport. These different exchanges have very different energetics, being opposed by $\Delta \psi$, electroneutral or driven by $\Delta \psi$ respectively. A knowledge of the exchange catalysed is necessary for quantitative understanding of the calcium cycle and its bioenergetics, and for elucidation of the mechanism of the calcium efflux carrier.

Electroneutral $\mathrm{Ca}^{2+} / 2 \mathrm{H}^{+}$antiport has been proposed by Fiskum \& Lehninger (1979) on the basis of kinetic measurements of $\mathrm{Ca}^{2+}$ and $\mathrm{H}^{+}$movements during $\mathrm{Ca}^{2+}$ efflux stimulated by acetoacetate, but the interpretation of their experiments is open to strong criticism (see Nicholls \& Crompton, 1980; Nicholls \& Åkerman, 1982). A similar

Abbreviations used: $\Delta \psi$, transmembrane difference in electrical potential (positive outside); $\Delta \mathrm{pH}$, transmembrane difference in $\mathrm{pH}$ (acid inside); TMA, tetramethylammonium; NTA, nitrilotriacetate; $\left[\mathrm{Ca}^{2+}\right]_{o}^{\mathrm{f}}$, extramitochondrial free $\mathrm{Ca}^{2+}$ concentration. conclusion that the carrier catalyses $\mathrm{Ca}^{2+} / 2 \mathrm{H}^{+}$ antiport was reached by Maglova et al. (1982). Zoccarato \& Nicholls $(1981,1982)$ have suggested that $\mathrm{Ca}^{2+} / 1 \mathrm{H}^{+}$antiport operates. In heart, the number of $\mathrm{Na}^{+}$exchanged for each $\mathrm{Ca}^{2+}$ is unknown, but indirect evidence indicates that it is 2 or 3 (Crompton et al., 1976, 1977; Crompton \& Heid, 1978; Affolter \& Carafoli, 1980; Hayat \& Crompton, 1982).

In this paper I show that the calcium efflux carrier of liver mitochondria is electroneutral, i.e. catalyses $\mathrm{Ca}^{2+} / 2 \mathrm{H}^{+}$antiport.

\section{Experimental \\ Mitochondria}

Mitochondria were isolated by conventional methods (Chappell \& Hansford, 1972) in 250 mMsucrose $/ 5 \mathrm{~mm}$-Tris/ $\mathrm{HCl} / 1 \mathrm{~mm}$-(potassium) EGTA, $\mathrm{pH} 7.4$, washed once in $250 \mathrm{~mm}$-sucrose $/ 5 \mathrm{~mm}^{-}$ Tris/HCl, $\mathrm{pH} 7.4$, and kept on ice until use. Mitochondrial protein was assayed by a biuret method (Gornall et al., 1949).

\section{Free calcium concentration}

This was measured with a Radiometer F2112 calcium-sensitive electrode and K801 reference connected to a Radiometer PHM64 pH meter and Bryans 28000 chart recorder. The electrodes were inserted into a plastic vessel of $3 \mathrm{ml}$ capacity, magnetically stirred and open to the air, maintained at $30^{\circ} \mathrm{C}$. Except where otherwise stated all experiments were carried out in a medium containing $250 \mathrm{mM}$-sucrose, $5 \mathrm{mM}$-(TMA) Hepes, $10 \mathrm{mM}$ (TMA) succinate, $10 \mathrm{mM}$-(TMA) acetate, $1 \mathrm{mM}$ - 
(TMA) NTA, $5 \mu \mathrm{M}$-rotenone, $\quad 20 \mu \mathrm{M}$-methylamine $/ \mathrm{HCl}, 200 \mathrm{nM}$-methyltriphenylphosphonium bromide, brought to $\mathrm{pH} 7.1$ with TMA hydroxide. Total calcium measured by atomic absorption spectrophotometry was $22 \mu \mathrm{M}$. The signal from the electrode was calibrated by adding known amounts of standard $10 \mathrm{~mm}-\mathrm{CaCl}_{2}$ to the medium and calculating free $\left[\mathrm{Ca}^{2+}\right]$ using the algorithm of Fabiato \& Fabiato (1979) on a BBC microcomputer, using apparent stability constants at $\mathrm{pH} 7.1$ of $5873 \mathrm{M}^{-1}$ for Ca-NTA (Dippenaar \& Brand, 1982), $15.68 \mathrm{M}^{-1}$ for $\mathrm{Ca}$-succinate and $3.38 \mathrm{M}^{-1}$ for Ca-acetate (Martell \& Smith, 1977).

\section{$\Delta \psi, \Delta p H$ and matrix volume}

These were measured with radioisotopes. Radiochemicals present were either $0.05 \mu \mathrm{Ci}$ of $\left[{ }^{3} \mathrm{H}\right]-$ methyltriphenylphosphonium $/ \mathrm{ml}$ for $\Delta \psi$, or $1 \mu \mathrm{Ci}$ of ${ }^{3} \mathrm{H}_{2} \mathrm{O} / \mathrm{ml}$ and $0.14 \mu \mathrm{Ci}$ of $\mathrm{D}-\left[1{ }^{14} \mathrm{C}\right] \mathrm{mannitol} / \mathrm{ml}$ for matrix volume, or $1 \mu \mathrm{Ci}$ of $\left[6,6^{\prime}(\mathrm{n})-{ }^{3} \mathrm{H}\right]-$ sucrose $/ \mathrm{ml}$ and $0.14 \mu \mathrm{Ci}$ of $\left[{ }^{14} \mathrm{C}\right]$ methylamine $/ \mathrm{ml}$ for $\Delta \mathrm{pH}$. Mitochondria ( $2 \mathrm{mg}$ of protein $/ \mathrm{ml}$ ) were added, then, at the times shown in Fig. $3,1 \mathrm{ml}$ samples were taken in triplicate and centrifuged. Supernatant and pellet were assayed for radioactivity on an LKB Rackbeta scintillation counter with quench corrections. $\Delta \mathrm{pH}$, matrix volume and $\Delta \psi$ (using a binding correction factor of 0.33 for methyltriphenylphosphonium) were calculated as described in Brown \& Brand (1985).

\section{Correction for methylamine binding}

This was assessed by imposing known $\mathrm{pH}$ gradients (acid inside) and measuring $\left[{ }^{14} \mathrm{C}\right]-$ methylamine uptake. Mitochondria $(5 \mathrm{mg}$ of protein $/ \mathrm{ml}$ ) were suspended in medium containing $5 \mathrm{mM}$-(TMA) Hepes, $5 \mu \mathrm{M}$-rotenone, $20 \mu \mathrm{M}$-methylamine $/ \mathrm{HCl}, 1 \mathrm{mM}$-(TMA) EGTA, $1 \mu \mathrm{M}$-antimycin and varying proportions of sucrose and $\mathrm{KCl}$ to a total osmolarity of $260 \mathrm{mosM}, \mathrm{pH} 7.0,25^{\circ} \mathrm{C}$. The medium contained either $1 \mu \mathrm{Ci}$ of $\left[{ }^{3} \mathrm{H}\right]$ sucrose $/ \mathrm{ml}$ and $0.1 \mu \mathrm{Ci}$ of ${ }^{86} \mathrm{RbCl} / \mathrm{ml}$, or $1 \mu \mathrm{Ci}$ of $\left[{ }^{3} \mathrm{H}\right]$ sucrose $/ \mathrm{ml}$ and $0.14 \mu \mathrm{Ci}$ of $\left[{ }^{14} \mathrm{C}\right] \mathrm{methylamine} / \mathrm{ml}$, or $1 \mu \mathrm{Ci}$ of ${ }^{3} \mathrm{H}_{2} \mathrm{O} / \mathrm{ml}$ and $0.14 \mu \mathrm{Ci}$ of $\left[{ }^{14} \mathrm{C}\right] \mathrm{manni}-$ tol $/ \mathrm{ml}$. Nigericin $(0.8 \mu \mathrm{g} / \mathrm{mg}$ of protein) was then added to equilibrate $\mathrm{K}^{+}$and $\mathrm{H}^{+}$gradients, and after $2 \mathrm{~min}$ the suspension was centrifuged and assayed as before. Addition of more nigericin did not affect the results, showing that equilibrium had been attained. Fig. 1 shows that methylamine binding was minimal. Methylamine accumulation was very similar to ${ }^{86} \mathrm{Rb}$ accumulation over a wider range of $\Delta \mathrm{pH}$ than employed in this paper. From the slope and intercept of the line in Fig. 1 a correction was applied by using the formula:

Corrected methylamine accumulation ratio $=$ 0.94 (observed accumulation ratio) -0.9

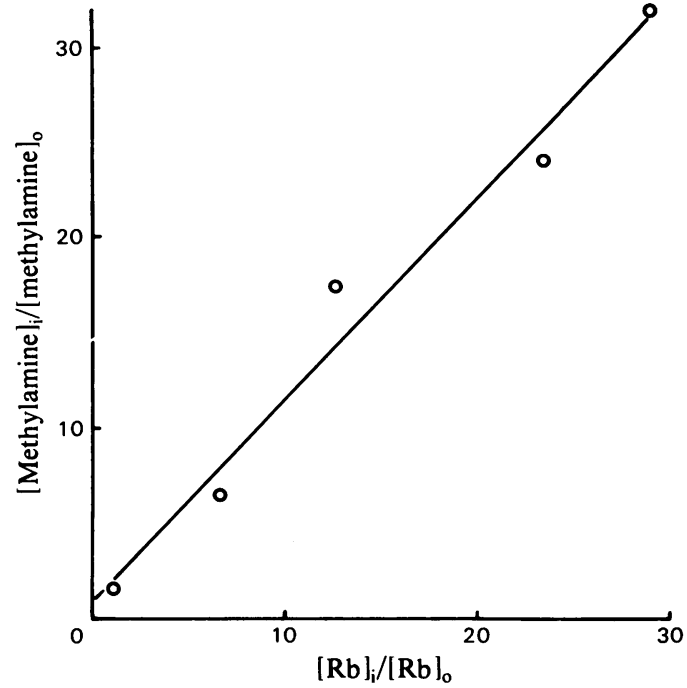

Fig. 1. Calibration of $\left[{ }^{14} \mathrm{C}\right]$ methylamine accumulation Mitochondria were suspended in a sucrose-based medium containing $0,0.5,3,20$ or $125 \mathrm{~mm}$ added $\mathrm{KCl}, \mathrm{pH}$ gradients (acid inside) were established by adding nigericin and measured by using ${ }^{86} \mathrm{Rb}$. For details see under 'Experimental'. The line drawn was calculated by linear regression and had slope of $1 / 0.94$ and intercept on the $\mathrm{Rb}$ axis of -0.895 .

As a check on the use of methylamine, some experiments similar to those in Fig. 3 were carried out with $\Delta \mathrm{pH}$ measured by using $0.8 \mu \mathrm{Ci}$ of $\left[{ }^{3} \mathrm{H}\right]$ acetate $/ \mathrm{ml}$. These confirmed that $\Delta \mathrm{pH}$ was large and reversed, but were less accurate since the acetate was excluded from the matrix space.

\section{Chemicals}

Radiochemicals were from Amersham International, except for $\left[{ }^{3} \mathrm{H}\right]$ methyltriphenylphosphonium, which was from New England Nuclear. Ruthenium Red was from Sigma and was purified as described by Luft (1971). Standard $10 \mathrm{~mm}-\mathrm{CaCl}_{2}$ was from $\mathrm{BDH}$.

\section{Results}

\section{Effect of $A 23187$}

The approach I report here to discover the pathway of $\mathrm{Ca}^{2+}$ efflux was to allow $\mathrm{Ca}^{2+}$ to come to the equilibrium catalysed by the $\mathrm{Ca}^{2+} / n \mathrm{H}^{+}$antiporter, then to add the ionophore $\mathrm{A} 23187$ and investigate whether the equilibrium was shifted. A23187 is thought to catalyse electroneutral $\mathrm{Ca}^{2+} / 2 \mathrm{H}^{+}$exchange (Reed \& Lardy, 1972; McLaughlin \& Eisenberg, 1975; Pfeiffer et al., 1976) so if there is no change in the equilibrium when it is added then the endogenous mitochondrial carrier must also catalyse $\mathrm{Ca}^{2+} / 2 \mathrm{H}^{+}$antiport. 
To allow discrimination between different possible values of $n$ in $\mathrm{Ca}^{2+} / n \mathrm{H}^{+}$antiport (see below), $\Delta \mathrm{pH}$ had to be made positive, i.e. acid inside. This was achieved by incubating mitochondria in a medium containing no added $\mathrm{K}^{+}$and allowing the endogenous $\mathrm{K}^{+} / \mathrm{H}^{+}$exchange to equilibrate the $\mathrm{K}^{+}$ and $\mathrm{H}^{+}$gradients. In preliminary experiments $\mathrm{I}$ added nigericin to facilitate this exchange, but it made little difference to $\Delta \mathrm{pH}$ so it was omitted from the experiments reported here. The value of $\Delta \tilde{\mu} \mathrm{H}^{+}$in this medium was quite low, about $120 \mathrm{mV}$ (Table 1). This was presumably because of the exclusion of succinate from the matrix by the reversed $\mathrm{pH}$ gradient and the effect of the acid matrix $\mathrm{pH}$ making succinate dehydrogenase more rate limiting. Since both $\Delta \psi$ and $\Delta \mathrm{pH}$ were measured, the low value of $\Delta \mu \mathrm{H}^{+}$does not affect the conclusions to be drawn from these experiments.

Fig. 2(a) shows that in this medium the mitochondria accumulated $\mathrm{Ca}^{2+}$, and addition of Ruthenium Red, which inhibits the uniporter, caused efflux. Efflux continued for more than $25 \mathrm{~min}$. At this point addition of A23187 caused further rapid efflux followed by a steady level of $\left[\mathrm{Ca}^{2+}\right]_{0}^{\mathrm{f}}$. This steady level represented the equilibrium catalysed by A23187, since addition of more
A23187 did not change $\left[\mathrm{Ca}^{2+}\right]_{o}^{\mathrm{f}}$ (results not shown). To reduce the time taken to reach equilibrium, all subsequent experiments were carried out as shown in Fig. 2(b), with Ruthenium Red added before the mitochondria to prevent uptake of $\mathrm{Ca}^{2+}$. This allowed a steady value of $\left[\mathrm{Ca}^{2+}\right]_{0}^{\mathrm{f}}$ to be reached within $15 \mathrm{~min}$. This value was the same as that seen after A23187 addition in Fig. 2(a) and did not change when A23187 was added. Clearly the steady state catalysed by the endogenous mitochondrial antiporter (Fig. $2 b$ ) is not experimentally different from that catalysed by A23187 (Figs. $2 a$ and $2 b$ ), i.e. the endogenous antiporter is not experimentally distinguishable from one catalysing $\mathrm{Ca}^{2+} / 2 \mathrm{H}^{+}$exchange in this experiment.

The question I then asked was whether $\mathrm{Ca}^{2+} / 2 \mathrm{H}^{+}$exchange on the antiporter would have been distinguishable from other modes of exchange, particularly $\mathrm{Ca}^{2+} / 1 \mathrm{H}^{+}$and $\mathrm{Ca}^{2+} / 3 \mathrm{H}^{+}$antiport. The rest of the results I report here show that it would have been.

\section{Thermodynamics of $\mathrm{Ca}^{2+} / \mathrm{nH}^{+}$antiport}

For the general case of a $\mathrm{Ca}^{2+} / n \mathrm{H}^{+}$antiport at equilibrium:

$$
\Delta \tilde{\mu} \mathrm{Ca}^{2+}=n \Delta \tilde{\mu} \mathrm{H}^{+}
$$

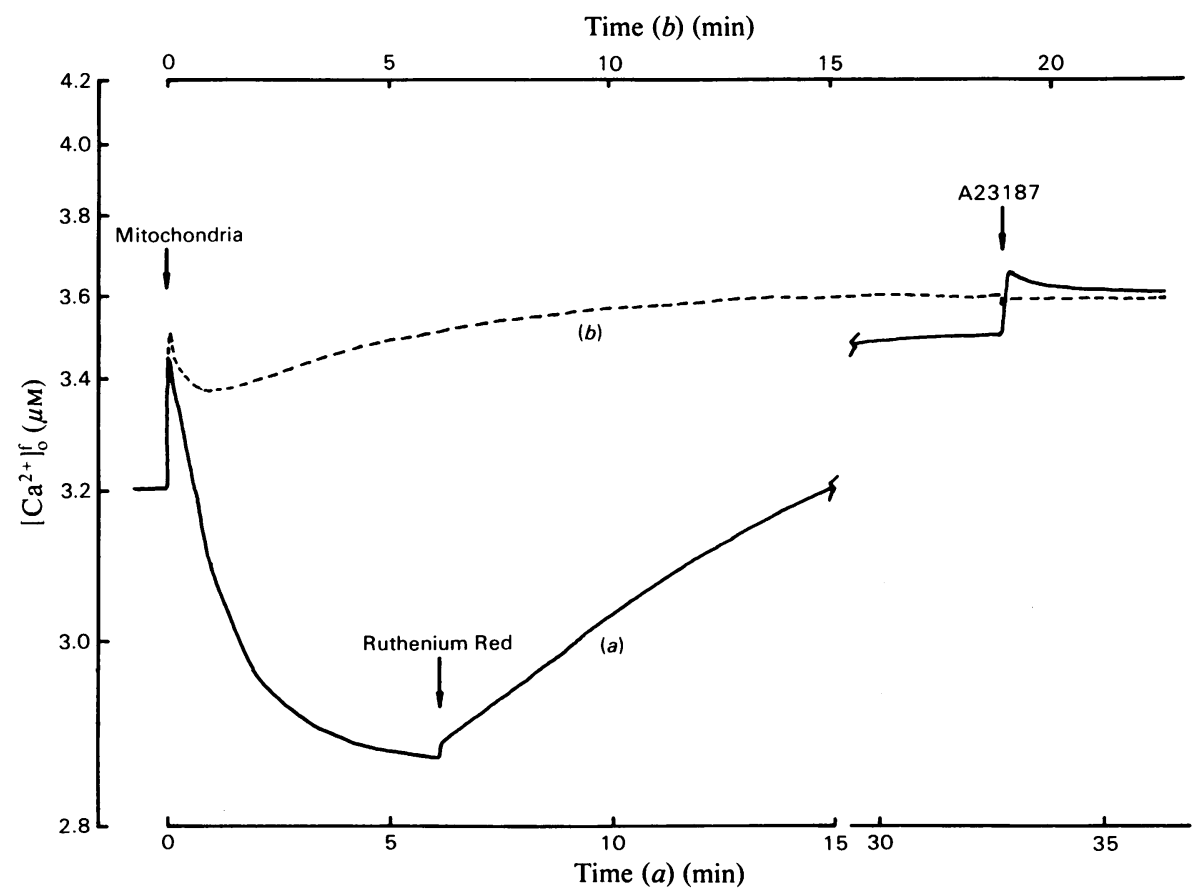

Fig. 2. Approach of the $\mathrm{Ca}^{2+}$ antiporter to equilibrium

Mitochondria ( $2 \mathrm{mg}$ of protein $/ \mathrm{ml}$ ) were suspended in medium, and $\left[\mathrm{Ca}^{2+}\right]_{0}^{\mathrm{f}}$ was measured with a calcium-sensitive electrode as described under 'Experimental'. In (b) Ruthenium Red ( $0.83 \mathrm{nmol} / \mathrm{mg}$ of protein) was added before the mitochondria; in (a) it was added where indicated. Where shown A23187 was added at $0.6 \mathrm{nmol} / \mathrm{mg}$ of protein. 
therefore:

$2 \Delta \psi-60 \log \left(\left[\mathrm{Ca}^{2+}\right]_{\mathrm{i}}^{\mathrm{f}} /\left[\mathrm{Ca}^{2+}\right]_{\mathrm{o}}^{\mathrm{f}}\right)=n \Delta \psi-60 n \Delta \mathrm{pH}$

where subscripts $\mathrm{i}$ and $\mathrm{o}$ refer to the intra- and extramitochondrial compartments respectively and superscript $f$ denotes free.

Rearranging:

$\left[\mathrm{Ca}^{2+}\right]_{\mathrm{i}}^{\mathrm{f}} /\left[\mathrm{Ca}^{2+}\right]_{\mathrm{o}}^{\mathrm{f}}=10 \exp [(2-n) \Delta \psi / 60+n \Delta \mathrm{pH}]$

The total amount of $\mathrm{Ca}^{2+}$ in the system able to participate in the equilibrium, $\mathrm{Ca}^{2+, t}{ }_{\text {io }}=$ $\mathrm{Ca}^{2+, t}{ }_{0}+\mathrm{Ca}^{2+, t}{ }_{i}$, i.e.:

$$
\mathrm{Ca}^{2+, \mathrm{t}_{\mathrm{io}}}=\left[\mathrm{Ca}^{2+}\right]_{\mathrm{o}}^{\mathrm{f}} \cdot B_{\mathrm{o}} \cdot V+\left[\mathrm{Ca}^{2+}\right]_{\mathrm{i}}^{\mathrm{f}} \cdot B_{\mathrm{i}} \cdot v
$$

where superscript $\mathrm{t}$ denotes total, $B_{\mathrm{o}}$ and $B_{\mathrm{i}}$ are $\left[\mathrm{Ca}^{2+}\right]^{\mathrm{t}} /\left[\mathrm{Ca}^{2+}\right]^{\mathrm{f}}$ in compartments $\mathrm{o}$ and $\mathrm{i}, V$ is the volume of the extramitochondrial compartment and $v$ is the volume of the intramitochondrial compartment.

Rearranging:

$$
\left[\mathrm{Ca}^{2+}\right]_{\mathrm{o}}^{\mathrm{f}}=\left(\mathrm{Ca}^{2+, \mathrm{t}}{ }_{\mathrm{io}}-\left[\mathrm{Ca}^{2+}\right]_{\mathrm{i}}^{\mathrm{f}} \cdot B_{\mathrm{i}} \cdot v\right) / B_{\mathrm{o}} \cdot V
$$

Substituting eqn. (1) in eqn. (2): known $\Delta \mathrm{pH}$ and matrix volume, as shown in Fig. 3 , where $\left[\mathrm{Ca}^{2+}\right]_{\mathrm{i}}^{\mathrm{f}}=\left[\mathrm{Ca}^{2+}\right]_{\mathrm{o}}^{\mathrm{f}} \cdot 10^{2 \wedge \mathrm{pH}}, \Delta\left[\mathrm{Ca}^{2+}\right]_{\mathrm{i}}^{\mathrm{t}}=$ $\left(3 \times 10^{-8}-\Delta \mathrm{Ca}^{\mathrm{t}}{ }_{0}\right) / v$ and $\mathrm{Ca}_{\mathrm{o}}^{\mathrm{t}}=V \cdot\left[\mathrm{Ca}^{2+}\right]_{0}^{\mathrm{r}} \cdot \boldsymbol{B}$.

The values of $B_{\mathrm{i}}$ obtained in this way were 12.2 and 10.2 for the experiments in Figs. $3(a)$ and $3(b)$ respectively. These are similar to those of Nicholls (1978) but much lower than the ones found by Coll et al. (1982) and Denton \& McCormack (1980) under rather different conditions. The differences may be due to the very acid matrix $\mathrm{pH}$ of less than pH6 in my experiments.

The values of $\left[\mathrm{Ca}^{2+}\right]_{0}^{\mathrm{f}}, \Delta \psi, \Delta \mathrm{pH}, V, v, B_{\mathrm{o}}$ and $B_{\mathrm{i}}$ for sample 2 were then substituted in eqn. (3) to calculate $\mathrm{Ca}^{\mathrm{t}}{ }_{i o}$ in the presence of A23187, where $n=2$. The values obtained were $15.2 \mathrm{nmol} / \mathrm{mg}$ of protein for the experiment in Fig. 3(a) and $19.3 \mathrm{nmol} / \mathrm{mg}$ of protein for Fig. 3(b). These agreed with, but were a little less than, the values found by direct measurement using atomic absorption spectrophotometry (16.8 and $25.2 \mathrm{nmol} / \mathrm{mg}$ of protein), showing that most, but not all, of the calcium in the mitochondria was able to participate in the equilibrium in these experiments.

$$
\left[\mathrm{Ca}^{2+}\right]_{\mathrm{o}}^{\mathrm{f}}=\left(\mathrm{Ca}^{2+, \mathrm{t}_{i o}}-\left[\mathrm{Ca}^{2+}\right]_{\mathrm{o}}^{\mathrm{f}} \cdot B_{\mathrm{i}} \cdot v \cdot 10 \exp [(2-n) \Delta \psi / 60+n \Delta \mathrm{pH}]\right) / B_{\mathrm{o}} \cdot V
$$

Rearranging:

$$
\mathrm{Ca}^{2+, t_{\text {io }}}=\left[\mathrm{Ca}^{2+}\right]_{\mathrm{o}}^{\mathrm{f}}\left\{B_{\mathrm{o}} \cdot V+B_{\mathrm{i}} \cdot v \cdot 10 \exp [(2-n) \Delta \psi / 60+n \Delta \mathrm{pH}]\right\}
$$

and

$$
\left[\mathrm{Ca}^{2+}\right]_{\mathrm{o}}^{\mathrm{f}}=\mathrm{Ca}^{2+, \mathrm{t}_{\mathrm{io}}} /\left(B_{\mathrm{o}} \cdot V+B_{\mathrm{i}} \cdot v \cdot 10 \exp [(2-n) \Delta \psi / 60+n \Delta \mathrm{pH}]\right)
$$

\section{Predicted $\left[\mathrm{Ca}^{2+}\right]_{\mathrm{o}}^{\mathrm{f}}$ for different values of $n$}

Eqns. (3) and (4) were then applied to the data obtained from the experiments described in Fig. 3. This allowed calculation of the value of $\left[\mathrm{Ca}^{2+}\right]_{0}^{\mathrm{f}}$ which would be predicted by different values of $n$ in $\mathrm{Ca}^{2+} / n \mathrm{H}^{+}$antiport. Fig. 3(a) shows the steady state $\left[\mathrm{Ca}^{2+}\right]_{0}^{\mathrm{f}}$ achieved by mitochondria treated as in Fig. 2(b). Fig. 3(b) shows an identical experiment but with extra $\mathrm{CaCl}_{2}$ added to the medium before the addition of mitochondria. At the points marked in Fig. 3, samples were taken from exactly parallel incubations and assayed for $v, \Delta \psi$ and $\Delta \mathrm{pH} . v$ was found to be $0.21 \mu \mathrm{l} / \mathrm{mg}$ of protein. This was a low value, but it is not unreasonable since the major intramitochondrial cation is $\mathrm{K}^{+}$, and much of this would have left the matrix in exchange for $\mathrm{H}^{+}$in the long approach to the steady state. Table 1 shows the values of $\Delta \psi$ and $\Delta \mathrm{pH}$ at each of the points marked in Fig. 3.

$B_{\mathrm{i}}$ was easily determined by applying the principle of conservation of matter following addition of a pulse of $\mathrm{CaCl}_{2}$. It was calculated as $\Delta\left[\mathrm{Ca}^{2+}\right]_{\mathrm{i}}^{\mathrm{t}} / \Delta\left[\mathrm{Ca}^{2+}\right]_{\mathrm{i}}^{\mathrm{f}}$ before and after addition of $30 \mathrm{nmol}$ of $\mathrm{CaCl}_{2}$ in the presence of $\mathrm{A} 23187$ at
Finally the predicted value of $\left[\mathrm{Ca}^{2+}\right]_{\circ}^{\mathrm{f}}$ at equilibrium from sample 1 was calculated from eqn. (4) for different values of $n$. This assumed that $B_{\mathrm{i}}$ did not change when A23187 was added, which seems reasonable. The values calculated in this way are reported in Table 2.

I then used the predicted values of $\left[\mathrm{Ca}^{2+}\right]_{0}^{\mathrm{f}}$ in Table 2 to determine whether the equilibrium catalysed by a $\mathrm{Ca}^{2+} / n \mathrm{H}^{+}$antiporter would have been measurably disturbed by addition of A23187. Values of $n$ less than 2 predict very low $\left[\mathrm{Ca}^{2+}\right]_{0}^{\mathrm{f}}$ because of the contribution of $\Delta \psi$ to uptake. A23187 would have caused huge changes in $\left[\mathrm{Ca}^{2+}\right]_{0}^{\mathrm{f}}$. This did not happen, so values of $n$ less than 2 are excluded. With $n$ greater than 2 most of the $\mathrm{Ca}^{2+}$ would be extramitochondrial, driven out by $\Delta \psi$, and the differences in predicted $\left[\mathrm{Ca}^{2+}\right]_{0}^{\mathrm{f}}$ are not so great. However, they would still have been easily distinguished from the equilibrium catalysed by A23187, and values of $n$ greater than 2 are therefore also excluded. The main reason this experiment can distinguish between $n=2$ and $n>2$ is that $\Delta \mathrm{pH}$ is reversed. This means that $n=2$ gives substantial accumulation of $\mathrm{Ca}^{2+}$ (about 200-fold) at equilibrium, whereas with $n>2, \Delta \psi$ dominates 


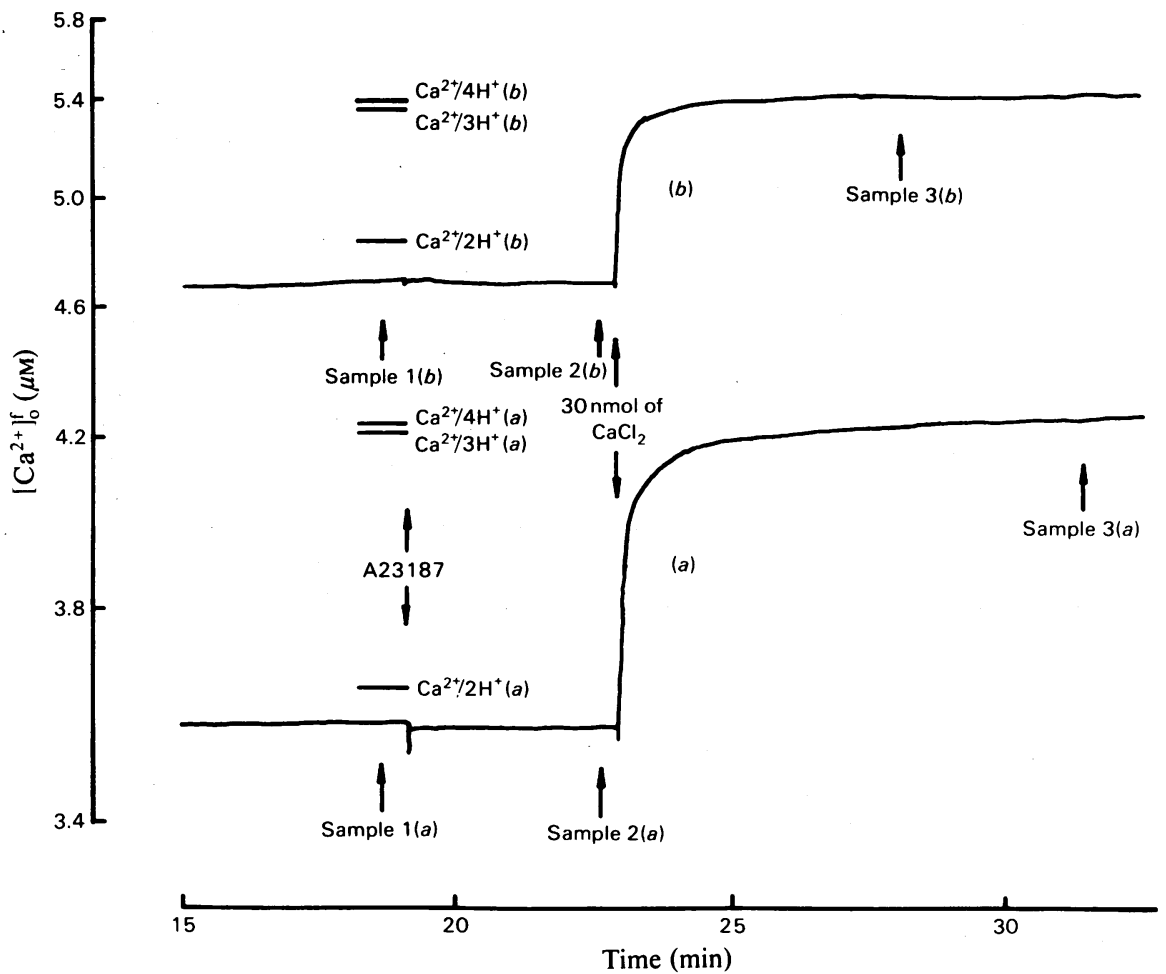

Fig. 3. Effect of $\mathrm{A} 23187$ on $\left[\mathrm{Ca}^{2+}\right\}_{o}$ in the steady state

Mitochondria were allowed to come to a steady state in the presence of Ruthenium Red as described for Fig. $2(b)$. In (b) an additional $8.33 \mathrm{nmol}$ of $\mathrm{CaCl}_{2} / \mathrm{mg}$ of protein was added to the medium before the mitochondria. Parallel experiments using radioactive markers for measurement of intracellular volume, $\Delta \mathrm{pH}$ and $\Delta \psi$ were carried out simultaneously, with radioactive samples taken at the times marked on the traces. Where indicated $0.6 \mathrm{nmol}$ of A23187/mg protein was added. The bars marked $\mathrm{Ca}^{2+} / 3 \mathrm{H}^{+}(a)$ etc. show the predicted value of $\left[\mathrm{Ca}^{2+}\right]_{\mathrm{o}}^{\mathrm{f}}$ for that exchange in experiment $(a)$ or $(b)$.

Table 1. $\Delta \psi$ and $\Delta p H$ for the samples marked in Fig.3

For details see Fig. 3 and under 'Experimental'.

$\begin{array}{ccccccc}\text { Sample } & \Delta \psi(\mathrm{mV}) & \Delta \mathrm{pH}(\mathrm{pH} \text { units) } & {\left[\mathrm{Ca}^{2+}\right]_{\circ}^{\mathrm{f}}(\mu \mathrm{M})} & {\left[\mathrm{Ca}^{2+}\right]_{\circ}^{\mathrm{t}}(\mu \mathrm{M})} & {\left[\mathrm{Ca}^{2+}\right]_{\mathrm{i}}^{\mathrm{f}}(\mu \mathrm{M})} & B_{\mathrm{i}} \\ 1(a) & 187.4 & +1.183 & 3.58 & 24.85 & & \\ 2(a) & 192.9 & +1.210 & 3.57 & 24.78 & 939 & 12.18 \\ 3(a) & 170.9 & +1.198 & 4.26 & 29.48 & 1060 & \\ 1(b) & 187.1 & +1.124 & 4.70 & 32.46 & & \\ 2(b) & 185.9 & +1.194 & 4.70 & 32.46 & 1148 & \\ 3(b) & 169.2 & +1.150 & 5.46 & 37.58 & 1089 & 10.16\end{array}$

and most of the $\mathrm{Ca}^{2+}$ is excluded from the matrix. The predicted values of $\left[\mathrm{Ca}^{2+}\right]_{0}$ are shown on Fig. 3 for $\mathrm{Ca}^{2+} / 2 \mathrm{H}^{+}, \mathrm{Ca}^{2+} / 3 \mathrm{H}^{+}$and $\mathrm{Ca}^{2+} / 4 \mathrm{H}^{+}$antiport to show the size of the changes expected when ionophore is added; changes in $\left[\mathrm{Ca}^{2+}\right]_{o}^{\mathrm{f}}$ of this magnitude would not have escaped detection.

The predicted value of $\left[\mathrm{Ca}^{2+}\right]_{0}^{\mathrm{f}}$ for $\mathrm{Ca}^{2+} / 2 \mathrm{H}^{+}$ antiport differs a little from the observed one. This is because the value of $\Delta \mathrm{pH}$ was slightly different before and after A23187 addition. This may be caused by the experimental variations in measured $\Delta \mathrm{pH}$, or it might represent a residual Ruthenium
Red-insensitive contribution from the $\mathrm{Ca}^{2+}$-uniporter which could pull the steady state $\left[\mathrm{Ca}^{2+}\right]_{0}^{\mathrm{f}_{0}}$ a little below the equilibrium value for electroneutral exchange. It is possible that $\mathrm{Ca}^{2+} / 3 \mathrm{H}^{+}$antiport is occurring with the steady state pulled by residual uniport activity to the same $\left[\mathrm{Ca}^{2+}\right]_{0}^{\mathrm{f}}$ as the equilibrium for $\mathrm{Ca}^{2+} / 2 \mathrm{H}^{+}$antiport, but this seems highly improbable.

The difference between the predicted and observed values of $\left[\mathrm{Ca}^{2+}\right]_{0}^{\mathrm{f}}$ for values of $n$ other than 2 increases as $B_{\mathrm{i}}$ increases. Thus, if my estimate of $B_{\mathrm{i}}$ is low, then the conclusion that the endogenous 
Table 2. Predicted values of $\left[\mathrm{Ca}^{2+}\right\}_{o}$ for different modes of $\mathrm{Ca}^{2+} / \mathrm{nH}^{+}$antiport at equilibrium for the experiment of Fig. 3

See the text for details.

\begin{tabular}{|c|c|c|}
\hline \multirow[b]{2}{*}{ Antiport } & \multicolumn{2}{|c|}{ Predicted $\left[\mathrm{Ca}^{2+}\right]_{0}^{\mathrm{f}}(\mathrm{M})$} \\
\hline & Expt. (a) & Expt. (b) \\
\hline $\mathrm{Ca}^{2+}$ uniport & $3.320 \times 10^{-9}$ & $5.171 \times 10^{-}$ \\
\hline $\mathrm{Ca}^{2+} / 1 \mathrm{H}^{+}$ & $2.709 \times 10^{-7}$ & $5.160 \times 10$ \\
\hline $\mathrm{Ca}^{2+} / 2 \mathrm{H}^{+}$ & $3.618 \times 10^{-6}$ & $4.873 \times 10^{-6}$ \\
\hline & $4.216>$ & $5.388 \times 10^{-}$ \\
\hline & $4.224 \times 10^{-6}$ & $5.394 \times 10$ \\
\hline $\mathrm{Ca}^{2+} / 5 \mathrm{H}^{+}$ & $4.224 \times 10^{-6}$ & $5.394 \times 10^{-6}$ \\
\hline
\end{tabular}

antiport is electroneutral would be strengthened. If my estimate of $B_{\mathrm{i}}$ is high the predicted differences are less, but they would still have been seen even when $B_{\mathrm{i}}=1$.

The possibility that the observed electroneutral antiport represents only the net reaction of, for example, $\mathrm{Ca}^{2+} / 2 \mathrm{C}^{+}$exchange plus $\mathrm{C}^{+} / \mathrm{H}^{+}$exchange is not excluded by my data. Indeed, it is not impossible that there could be some contribution of $\mathrm{Ca}^{2}+/ 2 \mathrm{Na}^{+}$antiport in these experiments (see Goldstone \& Crompton, 1982). However, because of the low concentration of $\mathrm{Na}^{+}$and $\mathrm{K}^{+} \mathrm{I}$ do not consider these other exchanges to be likely in my experiments.

\section{Discussion}

These experiments show unambiguously that the $\mathrm{Ca}^{2+}$ efflux carrier of rat liver mitochondria catalyses an electroneutral reaction. The carrier performs the same exchange as the ionophore A23187, i.e. $\mathrm{Ca}^{2+} / 2 \mathrm{H}^{+}$antiport.

Previous evidence for electroneutrality has been provided by Fiskum \& Lehninger (1979), who showed kinetically that about $2 \mathrm{H}^{+}$disappeared from the medium per $\mathrm{Ca}^{2+}$ appearing during acetoacetate-induced $\mathrm{Ca}^{2+}$ release. As discussed by Nicholls \& Crompton (1980) and Nicholls \& Akerman (1982), the interpretation is open to doubt since acetoacetate causes collapse of $\Delta \psi$ (Nicholls \& Brand, 1980; Beatrice et al., 1980, 1982; Bardsley \& Brand, 1982; Siliprandi et al., 1983). The results of Fiskum \& Lehninger (1979) could well have been caused by enhanced $\mathrm{H}^{+}$leak and electrically compensating $\mathrm{Ca}^{2+}$ efflux on the uniporter, and might have no relevance to the exchange catalysed by the antiporter. Lack of sensitivity to Ruthenium Red cannot exclude the possibility of uniport activity, since $\mathrm{Ca}^{2+}$ efflux by uniport can occur under some uncoupled conditions in the presence of this inhibitor (Jurkowitz et al., 1983; Bernardi et al., 1984). This criticism does not apply to the results of Maglova et al. (1982) who carried out similar kinetic experiments on $\mathrm{Ca}^{2+}$ release stimulated by Ruthenium Red and showed that $\Delta \psi$ did not drop during their experiments.

Zoccarato \& Nicholls $(1981,1982)$ have suggested that the enhanced rate of $\mathrm{Ca}^{2+}$ efflux seen when uncouplers are added in the presence of Ruthenium Red might be evidence for $\mathrm{Ca}^{2+} / 1 \mathrm{H}^{+}$ antiport. Thus $\Delta \mathrm{pH}$ would drive efflux but $\Delta \psi$ would oppose it, and uncoupling could stimulate by decreasing $\Delta \psi$ more than $\Delta \mathrm{pH}$. The data I present here suggest that this is not the case and support the view of Bernardi et al. (1984) that the effect is due to incomplete inhibition of the uniporter by Ruthenium Red under these conditions.

I conclude that the $\mathrm{Ca}^{2+}$ antiporter of liver mitochondria catalyses exchange of $\mathrm{Ca}^{2+}$ for $2 \mathrm{H}^{+}$.

\section{References}

Affolter, H. \& Carafoli, E. (1980) Biochem. Biophys. Res. Commun. 95, 193-196

Åkerman, K. E. O. (1978) Arch. Biochem. Biophys. 189, 256-262

Bardsley, M. E. \& Brand, M. D. (1982) Biochem. J. 202, 197-201

Beatrice, M. C., Palmer, J. W. \& Pfeiffer, D. R. (1980) J. Biol. Chem. 255, 8663-8671

Beatrice, M. C., Stiers, D. L. \& Pfeiffer, D. R. (1982) J. Biol. Chem. 257, 7161-7171

Bernardi, P., Paradisi, V., Pozzan, T. \& Azzone, G. F. (1984) Biochemistry 23, 1645-1651

Brown, G. C. \& Brand, M. D. (1985) Biochem. J. 225, 399-405

Chappell, J. B. \& Hansford, R. G. (1972) in Subcellular Components-Preparation and Fractionation (Birnie, G. D., ed.), 2nd edn., pp. 77-91, Butterworth. London

Coll, K. E., Joseph, S. K., Corkey, B. E. \& Williamson, J. R. (1982) J. Biol. Chem. 257, 8696-8704

Crompton, M. \& Heid, I. (1978) Eur. J. Biochem. 91, 599608

Crompton, M., Capano, M. \& Carafoli, E. (1976) Eur. J. Biochem. 69, 453-462

Crompton, M., Kunzi, M. \& Carafoli, E. (1977) Eur. J. Biochem. 79, 549-558

Dippenaar, N. G. \& Brand, M. D. (1982) Biochem. J. 202, 731-737

Denton, R. M. \& McCormack, J. G. (1980) FEBS Lett. 119, 1-8

Fabiato, A. \& Fabiato, F. (1979) J. Physiol. (Paris) 75, 463-505

Fiskum, G. \& Cockrell, R. S. (1978) FEBS Lett. 92, 125128

Fiskum, G. \& Lehninger, A. L. (1979) J. Biol. Chem. 254, 6236-6239

Goldstone, T. P. \& Crompton, M. (1982) Biochem. J. 204, 369-371

Gornall, A. G., Bardawill, C. J. \& David, M. M. (1949) J. Biol. Chem. 177, 751-766

Hayat, L. H. \& Crompton, M. (1982) Biochem. J. 202, 509-518 
Jurkowitz, M. S., Geisbuhler, T., Jung, D. W. \& Brierley, G. P. (1983) Arch. Biochem. Biophys. 233, 120-128

Luft, J. H. (1971) Anat. Rec. 171, 347-368

Maglova, L. M., Holmuhamedov, E. L., Zinchenko, V. P. \& Evtodienko, Y. V. (1982) Eur. J. Biochem. 128, 159-161

Martell, A. E. \& Smith, R. M. (1977) Critical Stability Constants, vol. 3, p. 139, Plenum Press, New York

McLaughlin, S. \& Eisenberg, M. (1975) Annu. Rev. Biophys. Bioeng. 4, 335-366

Nicholls, D. G. (1978) Biochem. J. 176, 463-474

Nicholls, D. G. \& Åkerman, K. (1982) Biochim. Biophys. Acta 683, 57-88

Nicholls, D. G. \& Brand, M. D. (1980) Biochem. J. 188, 113-118

Nicholls, D. G. \& Crompton, M. (1980) FEBS Lett. 111, 261-268
Pfeiffer, D. R., Hutson, S. M., Kauffman, R. F. \& Lardy, H. A. (1976) Biochemistry 15, 2690-2697

Reed, P. W. \& Lardy, H. A. (1972) J. Biol. Chem. 247, 6970-6977

Saris, N.-E. \& Åkerman, K. E. O. (1980) Curr. Top. Bioenerg. 10, 103-179

Siliprandi, D., Siliprandi, S. \& Toninello, A. (1983) Eur. J. Biochem. 130, 173-175

Williamson, J. R., Cooper, R. H. \& Hoek, J. B. (1981) Biochim. Biophys. Acta 639, 243-295

Zoccarato, F. \& Nicholls, D. G. (1981) in Vectorial Reactions in Electron and Ion Transport in Mitochondria and Bacteria (Palmieri, F., Quagliariello, E., Siliprandi, N. \& Slater, E. C., eds.), pp. 277-280, Elsevier/North-Holland, Amsterdam

Zoccarato, F. \& Nicholls, D. G. (1982) Eur. J. Biochem. 127, 333-338 